\title{
Evaluation of Parking Performance in the Maulana Malik Ibrahim Gresik
}

(Case Study: Makam Terminal Maulana Malik Ibrahim)

\section{Mochammad Surono, Sapto Budi Wasono}

Narotama University, Surabaya Indonesia

\begin{abstract}
Along with the increase number of employees and pilgrims in Maulana Malik Ibrahim Graveyard from year to year, it certainly has an impact on the increasing volume of vehicles on its parking area. The avaibility of parking area that is not proportional to the volume of vehicles will certainly disrupt the orderliness and comfort of the parking users around Maulana Malik Ibrahim graveyard. The research method used for performance analysis is in the form of field survey by using the data of two wheels and four wheels vehicle parked in that area. In analyzing this parking performance surveyed on July $1^{\text {st }}$ $5^{\text {th }} 2018$, it is found that the highest volume of two wheels vehicles is 418 vehicles, with the highest accumulation of 43 vehicles on average the highest duration 209.50 minutes / vehicle, the highest turnover is 0.804 , the highest level of parking used is $80.43 \%$ and the number of available parking capacity of motorcycles is 230 plots, while the highest number of parking requests is 185 plots. Therefore, the available parking capacity for two wheels vehicle is still quite accommodating the number of vehicles parked. Meanwhile, for four wheels vehicles, it obtained that the highest volume is 442 vehicles, with the highest accumulation of 50 vehicles on average the highest duration of 115.50 minutes / vehicle, the highest turnover is 1,171 , the highest level of parking used is $117.14 \%$ and the number of available car parking capacity is 140 plots, with highest number of parking requests is 165 plots. Since the number of parking lots is the highest 25 plots, so that the available parking capacity is not enough to accommodate the number of vehicles parked.
\end{abstract}

Keywords: Parking, Capacity, Parking Space Unit (SRP), performance evaluation.

\begin{tabular}{ccc}
\hline Received & Revised & Published \\
${\text { April } 11^{\text {th }} 2019}^{\text {June } 14^{\text {th }} 2019}$ & September $30^{\text {th }} 2019$ \\
\hline
\end{tabular}

\section{INTRODUCTION}

Maulana Malik Ibrahim is the 11th descendant of Husayn ibn Ali. He is also called Sunan Gresik, Syekh Maghribi, or sometimes Makhdum Ibrahim As-Samarqandy. He is thought to have been born in Samarkand in Central Asia, in the early half of the 14th century. The version of Meinsma's Babad Tanah Jawi calls it Asmarakandi, following the Javanese tongue's pronunciation of As-Samarqandy. In folklore, someone called him Grandpa Pillow.

Malik Ibrahim is generally regarded as the first guardian to preach Islam on Java. He taught new ways to grow crops and embrace many people, namely the Javanese community who were marginalized by the end of Majapahit's rule. Malik Ibrahim tried to 
appeal to the public, which was being hit by the economic crisis and civil war. He built a place for religious learning in Leran, Gresik. In 1419, Malik Ibrahim died. His tomb is in the village of Gapura Wetan, Gresik, East Java.

To overcome this problem, of course, it is necessary to evaluate parking performance in the current conditions as a description of future plans, so that we do not find vehicles that do not get a parking lot or are not neatly arranged. availability of physical facilities supporting parking lots, dimensions of parking spaces that do not meet standards, driver behavior in parking vehicles at locations that do not fit their designations in the analysis of parking land requirements on construction

\section{LITERATURE REVIEW}

\section{General}

Parking is an immovable condition of a temporary vehicle (Directorate General of Land Transportation, 1996, 1). In addition to the above definition, there are experts who provide their definition of parking, namely:

1. Parking is the termination of a vehicle in a short period of time, or long in accordance with the needs of motorists and one network system that is inseparable from the transportation system. (Sebelas Maret University Surakarta, September 2006)

2. Parking is an immovable condition of a vehicle that is not temporary (Director General of Land Transportation Decree Number: 272 / Hk.105 / DRJD / 96):

The objectives of the parking policy as part of the transportation policy are as follows:

a. To control the number of vehicles entering an area,

b. Optimizing the function of the road so that it is in accordance with its role,

c. Improve traffic smoothness and safety.

d. Support other traffic restrictions

Determination of the location of parking facilities for the public in an area is carried out by the Regional Government and carried out by taking into account:

1. Safety and smooth traffic;

2. General regional spatial plan;

3. Ease for service users;

4. Environmental sustainability.

\section{Parking Characteristics}

Parking characteristics are as parameters that affect the use of parking lots.

\section{Parking Duration}

Is information that is very much needed to know the length of a parking vehicle. This 
information is known by observing the time the vehicle enters and when the vehicle exits:

Duration $=$ Tout - Tin

with:

Tout $=$ time when the vehicle exits the parking location,

Tin $=$ time when a vehicle enters a parking location

\section{Parking Accumulation}

Definition Parking accumulation is the maximum number of vehicles that can be parked at a certain time interval, and can be divided according to the category of purpose of the trip. Calculation of accumulated parking can use the equation:

Accumulation $=\mathrm{Ei}-\mathrm{Ex}$

with:

$\mathrm{Ei}=$ Entry (vehicle entering location)

Ex $=$ Exit (vehicle that exits location)

\section{Substitution Rate (Parking Turn Over)}

Parking Turn Over, is the level of parking space usage obtained by dividing the parking volume by the amount of space available for a certain period, the unit is a parking lot.

The amount of turn over parking can be obtained by the equation:

Turn over $=$

\section{Usage level}

Occupancy Rate, obtained from the sum of vehicles at certain intervals and divided by available parking space multiplied by $100 \%$.

\section{Parking Volume}

Parking volume is the number of vehicles included in the parking load, namely the number of vehicles per period of time. The time used by the vehicle stops for parking, in minutes or hours, stating the length of parking.

\section{Parking Capacity}

The capacity of the parking space is the maximum capacity of space in accommodating vehicles, while in this case is the volume of vehicles using the parking facilities. An overview of the above events gives the capacity of the parking facilities.

The formula used to calculate parking capacity is:

$\mathrm{KP}=$

with:

KP: Parking capacity (vehicle / hour)

S: Total available official plot (plot)

D: Average parking time (hours / vehicle)

\section{Parking Index}

Parking index is a comparison between accumulated parking and parking capacity. 
This value can show how much parking capacity has been filled in a parking lot. The parking index size indicates whether the parking capacity is problematic or not. The size of the parking index can be obtained by the equation:

Parking Index =

Where :

IP $<1$ means that parking capacity is not problematic

IP $=1$ means that parking needs are balanced, normal capacity

IP> 1 means the need for parking exceeds normal capacity.

\section{Average Parking Duration}

The average parking duration is the average parking time of all vehicles

$\mathrm{D}=$

with:

$\mathrm{D}=$ average vehicle parking duration

$d i=$ duration of vehicle to $i$ ( $i$ from vehicle to $i$ to $n$ )

\section{Amount of Parking Space Required}

$Z=$

with:

$Z$ = the required parking space

$\mathrm{Y}=$ number of vehicles parked at one time

$\mathrm{D}=$ average duration (hours)

$\mathrm{T}=$ survey duration (hours)

\section{Parking Policy}

Parking is defined as a place specifically used for vehicles to stop for safety. Other spaces that are intended to be used for the cessation of vehicles. Parking has a good purpose, controlling access traffic flow makes it easier, if someone cannot park his vehicle he cannot make the trip comfortable.

Current parking facilities and demand for parking spaces can be determined by policies and steps in improving parking services optimally (Ririh Sudirahardjo, 2004; 12)

The application of parking arrangements was carried out around the 1960s, which usually included (Tamin, 1997):

a. Plan parking facilities outside the area.

b. High penalties for parking violations.

c. Restrictions on parking spaces and roads.

d. Parking fee settings.

In general, parking policy involves 4 main elements, namely:

a. Selection and determination of objectives.

b. The methods used.

c. Decision-making.

d. Organizations or institutions that implement and which have the power to establish parking policies. 


\section{Parking Space Unit}

Effective size for laying vehicles (passenger cars, buses / trucks, or motorbikes), including free space and wide open doors for certain things if without explanation, SRP is SRP for passenger cars. (KD. No.272 / HK.105 / DRJD / 96)

Table 2.8 Vehicle Door Opening Width

\begin{tabular}{|l|l|c|}
\hline Door Openings Type & $\begin{array}{l}\text { User and / or } \\
\text { Allocation of Parking Facilities }\end{array}$ & Group \\
\hline $\begin{array}{l}\text { Open front / rear door } \\
55 \mathrm{~cm}\end{array}$ & $\begin{array}{l}\text { Employees / Guest office workers / } \\
\text { visitors to offices, commerce, } \\
\text { government, universities }\end{array}$ & I \\
\hline $\begin{array}{l}\text { Open front / rear door } \\
75 \mathrm{~cm}\end{array}$ & $\begin{array}{l}\text { Visitors are sports, entertainment / } \\
\text { recreation centers, hotels, supermarkets, } \\
\text { cinemas, hospitals }\end{array}$ & $\mathrm{III}$ \\
\hline $\begin{array}{l}\text { Open front door }+ \\
\text { wheelchair maneuver }\end{array}$ & Disabled people & \\
\hline
\end{tabular}

Source: Keputusan Menteri Perhubungan No. 66 (1993) 


\section{METHOD}

\section{A. Flow Chart}

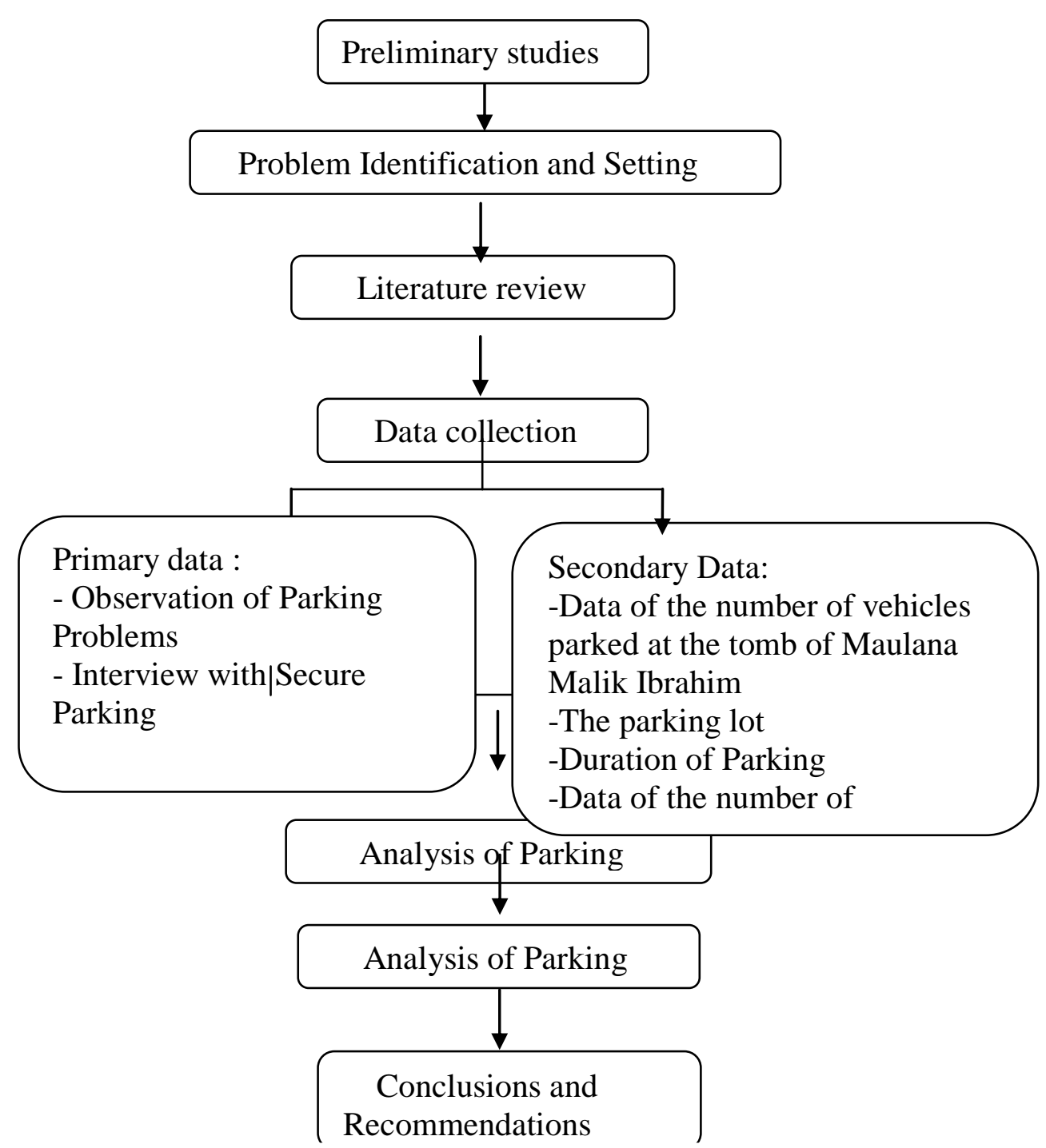

Gambar 3.1 Bagan alir penelitian 
Parking vehicle data is taken 5 days in the sample working hours until the patient's visiting hours, starting at $12.00-20.00$ WIB on effective pilgrimage days, starting July 1 - July 52015.

\section{Explanation of Research Flow chart}

Preliminary Study $\neg$

The purpose of this preliminary study is to determine the parameters of the data to be surveyed and the methods needed to determine the data in question. The steps of the activities to be carried out in the stages of this preliminary study are:

a. Identification of problems

b. Formulation of data collection objectives

c. Conducting literature studies

d. Defines the parameters to be studied

e. Formulate and determine the scope of the survey.

\section{Data collection $\neg$}

The data used in this study consists of two types of data, namely:

a. Primary data

Primary data is data obtained directly in the field. The primary data sought is the situation of parking conditions at the grave maulana malik Ibrahim grave during many visitor activities. The method used to obtain the data is by surveying and conducting direct interviews with secure parking.

b. Secondary data

Secondary data is data obtained from various data sources by holding records or quotes from data sources that have previously been processed by the relevant agencies. The secondary data survey is basically a support from primary data. The secondary data needed in preparing this task are:

1. Data on the number of vehicles parked at Ibrahim Gresik's Maulana Mailik Cemetery

2. Parking plan

3. Parking duration

\section{DISCUSSION}

\section{Parking duration}

Parking duration is the time span of a parking vehicle in a place (in minutes or hours), or in other words the length of parking for a vehicle in a parking lot. from parking management data can be taken for example the duration of vehicles parked in the grave malik Ibrahim

\section{Parking Accumulation}

Parking accumulation is the number of vehicles that are currently located in a parking area at certain intervals, and can be divided according to the category of purpose of the trip. in the attachment of data from the Graveyard parking management Maulana Malik Ibrahim the accumulated value can be known and in the following table. 


\section{Parking Volume}

Parking volume is the number of vehicles included in the parking load, namely the number of vehicles per period of time. the time used by vehicles for parking, in minutes or hours, states the length of parking. from the research data it can be seen the volume of vehicles parked at the Waru Family Partners Hospital.

\section{Parking Capacity}

The capacity of the parking space is the maximum capacity of the space in accommodating vehicles, in this case is the volume of vehicles using the parking facilities. the vehicle that uses this parking facility is reviewed from the process of coming, parking, and leaving the parking facilities. a review of the events mentioned above will provide the capacity of the parking facilities.

\section{Substitution Rate (Parking Turn Over)}

The turnover rate (Parking Turn Over), is the level of use of parking spaces obtained by dividing the parking volume by the number of parking spaces for a given period.

Parking space available (motorbike) $=240$ vehicles

Parking space available (car) $=140$ vehicles

\section{Level of Use}

The level of use (Occupancy Rate), obtained from the accumulation of vehicles at certain intervals divided by available parking space multiplied by $100 \%$.

\section{Parking Index}

Parking index is a comparison between accumulated parking and parking capacity. this value can indicate how much parking capacity has been filled. This parking index amount indicates whether the parking capacity is problematic or not.

Definition of problems: parking capacity is overloaded

Understanding is not problematic: normal parking capacity

Where if the value:

IP $<1$ means that parking capacity is not problematic

IP = 1 means that parking needs are balanced, normal capacity

IP> 1 means the need for parking exceeds normal capacity.

Motorcycle parking space $=230$

Car parking space $=140$

\section{Average Parking Duration}

The average parking duration is the average parking time of all vehicles. from survey data can be obtained the average parking duration.

\section{Amount of Parking Space Required}

From the survey data, it can be seen the amount of parking space needed for motorbikes and cars. 


\section{CONCLUSION}

Characteristics of motorcycle parking, namely: motorcycle parking volume of 418 vehicles with the highest accumulation of 43 vehicles and an average parking duration of 209.50 minutes / vehicle on Monday 4 July 2018. The highest turnover value is 0.804 and the highest parking usage rate is $80,43 \%$. The number of parking lots currently available is 230 parking lots. So that this capacity can still accommodate parking demand during peak hours of 185 vehicles, namely at $12.00-20.59$. So that the index value of motorbike parking at the malik ibrahim tomb for the time was not problematic.

Car park characteristics are: car parking volume of 442 vehicles with the highest accumulation of 50 vehicles and the average parking duration of 115.80 minutes / vehicle on Saturday 2 January 2016. The highest turnover value is 1.171 and the highest parking usage rate is $117.14 \%$. The number of parking lots currently available is 140 parking lots. So that this capacity cannot accommodate parking requests when the peak hours are 164 vehicles, namely at 19.00-19.29. So that the index value of the car park at the malik ibrahim tomb for the time is still problematic.

\section{Suggestion}

1. For recommendations that can be given to the parking management of the malik ibrahim tomb, you should start preparing further studies related to the availability of parking capacity, especially on car vehicles in the tomb of mailik ibrahim

2. Suggestions that can be given to the management of the parking of the malik ibrahim tomb, should anticipate an increase in numbers, especially in car vehicles for the future. If the development of the number of vehicles is not anticipated, it is feared that service to the public or visitor guests will decrease and make the tomb of mailik ibrahim lack parking space.

\section{REFERENCES}

Black,1981 " Langkah Utama dalam Meramalkan Kebutuhan Parkir "

Desi Ramayanti, Reza Rian Putra, 2011, "Rancang Bangun Aplikasi Plot Posisi Parkir Kendaraan Terdekat " Universitas Mercubuana, Jakarta

Departemen Perhubungan. 1996. "Keputusan Direktur Jendral perhubungan Darat Tentang Pedoman Teknis Penyelenggaraan Fasilitas Parkir”. Jakarta.

Direktorat Jendral Perhubungan Darat, 1998, "Pedoman Perencanaan dan Pengoperasian Fasilitas Parkir.," Direktorat Bina Sistem Lalu Lintas Angkutan Kota. Jakarta.

Firnas, adi, arifta, 2008 "Perencanaan Areal Parkir Surabaya Sport Center (SSC)" ITS Surabaya, Jawa timur

Internet: www.saft7.com, 2014 " Teknik Parkir " http//: www.saft7.comteknik-parkir Keputusan Menteri Perhubungan Nomor: KM 4 Tahun 1994 tentang Tata Cara Parkir Kendaraan Bermotor di Jalan. Jakarta: Menteri Perhubungan 
Keputusan Menteri Perhubungan No. 66 Tahun 1993 tentang Fasilitas Parkir Untuk Umum. Jakarta: Menteri Perhubungan

Keputusan Menteri Perhubungan Nomor: KM 4 Tahun 1994 tentang Tata Cara Parkir Kendaraan Bermotor di Jalan. Jakarta: Menteri Perhubungan

Khairul, Fahmi, 2012 "Analisa Kapasitas Ruang Parkir Pasar Modern Kota Pasir Pengaraian" Universitas Brawijaya Malang

Putu Alit, Suthayana, Muhammad, 2012, "Analisa Dan Karakteristik Kebutuhan Ruang Parkir Pada Pusat Perbelanjaan Di Kabupaten Bandung", ITB, Bandung.

Rahmat, Ali, Hamdani, 2015, "Evaluasi Kinerja Dan Kebutuhan Ruang Parkir Di Kantor Dinas Perhubungan Kota Surabaya", Universitas Narotama, Surabaya

Setiawan, Eko, 2014, "Evaluasi Kinerja Parkir di Universitas Narotama Surabaya", Universitas Narotama, Surabaya

Sri, Wiwoho, Mudjanarko, 2013, "Behavior Model Of Motorcycle User In Selecting Parking Location", Journal International

Universitas Sebelas Maret, September 2006 “ Kuliah Rekayasa Lalulintas "Surakarta.

Wibowo, Aries, 2010, "Analisa Kebutuhan Lahan Parkir pada Pembangunan Carrefour Ngagel.", ITS, Surabaya.

Yusandi, aswad, 2014 "Analisa Kebutuhan Parkir Pada Rumah Sakit Kelas B Di Kota Medan" UNEJ , Jakarta 